\title{
Fostering Student Awareness of Team Skills: A Participative \\ Team Formation Process for Class Projects
}

\author{
Gregory C. Berka, PhD \\ Assistant Professor, McColl School of Business \\ Queens University of Charlotte \\ Amber L. D. Greenwood, MA \\ PhD Student, Organizational Science \\ University of North Carolina at Charlotte \\ Jae Hwan Lee, PhD \\ Assistant Professor, Hamline School of Business \\ Hamline University
}

\begin{abstract}
This essay outlines a participative team formation process for class projects with resources to support instructors in implementing this process. This hybrid process, integrating self-selection and teacher assigned methods, includes four touch points that foster students' awareness of effective team behaviors and the presence (or absence) of these behaviors within themselves and in team members. The awareness can provide students the foundation for developing team skills-beneficial in both team projects and in organizational teams.
\end{abstract}

Teams and teamwork are a key competence in the workplace as many employers value interpersonal skills, teamwork skills, and team collaboration (Baird \& Parayitam, 2019; Kruse, 2020). Scholarship of Teaching and Learning (SoTL) research across many academic disciplines highlights the importance of preparing students to work in organizational teams (Burbach et al., 2010; Howe et al., 2001; Nilson, 2010; Stevenson et al., 2012). For example, an increasing number of instructors have undergone programs of instruction in the effective use of teams to achieve significant improvement in their teamwork knowledge, skills, and abilities (Burbach et al., 2010). Schools of social work and clinical sites have made significant efforts to develop educational curricula and clinical programs which prepare social workers to work on interdisciplinary geriatric health care teams (Howe et al., 2001).

Studies of team/group class projects display a variety of approaches to developing effective team skills (DuFrene \& Lehman, 1996; Jahanbakhsh, 2017; Opatrny et al., 2014), with many focused on teaching students about teamwork prior to the team experience (Prichard et al., 2004, 2006; Snyder, 2008). We build on the premise that student-centered activities prior to the actual teamwork can lead to an improved team experience and share a refined team formation process that provides multiple opportunities for student awareness and understanding of effective teammate behaviors for the specific class project.

Hybrid approaches to team formation have gained increased attention among SoTL researchers (Barkley et al., 2014). Our proposed process is a new hybrid approach that integrates the two most popular team formation methods-self-selection and teacher assignment (Decker, 1995; Baepler et al., 2016). The process guides students to 
identify, understand, self-assess, and rank teammate preferences based on team behaviors specific to the class project-setting the foundation for learning and development (Nilson, 2010). Informed by the student survey data and teammate preferences, instructors then create the student teams.

The process is designed to create an effective learning experience for students through enhanced understanding of the specific class project, their teammates' characteristics, the goals, and overall effective team behaviors. It also encourages selfregulation, which can increase a student's awareness of, and motivation for, effective project-related behaviors (Weimer, 2010). The significance of our approach is well supported by the existing literature. First, research indicates both goal and process clarity in conjunction with team potency, or team members' shared beliefs about their collective capabilities (Campion et al., 1993), are associated with increased team effectiveness and team-level organizational citizenship behaviors (Hu \& Liden, 2011). Second, studies on shared mental models in teams, or mutual understanding of team/member characteristics and goals, display positive association with effective team processes and team performance (DeChurch \& Mesmer-Magnus, 2010; Edwards et al., 2006). To the contrary, a lack of awareness of team goals and collective understanding of capabilities can lead to poorer team performance. Last, an understanding of team goals and capabilities can positively influence student performance (Turan et al., 2009).

\section{Participative Process for Team Formation Overview with Authors' Reflections}

The participative process for forming student teams prompts students to identify and consider the key factors contributing to effective teams for the specific class project. The process design is customizable to any group project-forging multiple opportunities (or touch points) to prompt awareness regardless of discipline, content, duration, and deliverables. See Diagram 1 for a summary of the four touch points, the estimated timing, and posited outcomes of the process.

\section{Diagram 1}

\section{Participative Team Formation Process}

\begin{tabular}{|lc|c|c|}
\hline \multicolumn{1}{|c|}{$\begin{array}{c}\text { Team Success } \\
\text { Factors Touch Points }\end{array}$} & Timing & $\begin{array}{c}\text { Increased Awareness } \\
\text { (Learning) }\end{array}$ \\
\hline $\begin{array}{l}\text { Identification and } \\
\text { Explanation (A) }\end{array}$ & Class 1 \\
\hline Self-Assessment (B) & After Class \\
\hline \multicolumn{2}{|c|}{1}
\end{tabular}




\section{Identification and Explanation (Touch Point A)}

As displayed in Diagram 1, students begin by collectively identifying and explaining key team success factors (i.e., behaviors, characteristics, skills, and abilities) that aid effective teamwork for the specific class project. To help students focus on the specific class project, the instructor can introduce and explain the project prior to initiating this activity. Based on our experiences, there are often factors (e.g., communication, shared software, availability) that are important for most team projects. If instructors desire to tie these factors specifically to the class project, they can ask why the factor is relevant for this team project. In addition to helping students understand the project, explanations and examples foster clarity regarding what the team will need to do for an effective experience.

Prompting students to identify and explain team success factors for the specific project is foundational to the process, and likely, the most important part. In a class discussion (in-person or synchronous online), small group discussion can effectively prepare a large class conversation. Each small group may generate three or four key success factors to share. In an asynchronous online course, an online discussion forum can be configured requiring students to post before seeing others' posts - potentially facilitating increased quantity of ideas. In addition, requiring replies to peers' posts can deepen students' understanding of the factors.

A significant issue associated with team projects across all disciplines is students misunderstanding integral aspects of the project. All course modalities provide instructors an opportunity to clarify expectations, requirements, or key details associated with the team project if they notice confusion or incorrect information surfacing.

\section{Self-Assessment (Touch Point B)}

After the team success factors are identified and understood in Touch Point A, students consider their proficiency across all those factors via a self-assessment survey. Depending on the class and project, the questions on the self-assessment survey can vary greatly. We provide an example survey in Table 1 that was used for a team project requiring a presentation. Creating surveys may sound cumbersome, but after the process is initially completed, the base survey design and questions can be repurposed with small edits for future classes. Googleforms.com is an easy resource to build quick surveys with downloadable data.

While teaching an Introduction to Statistics course in Sociology, one author found it beneficial to design a few survey questions with students as this helped them to understand the concept of operationalizing the factors (variables) discussed in class. See Appendix A for a pool of sample survey questions generated by students. When creating or adapting a full survey for a class project, instructors may seek to limit the survey to the questions most valuable for team formation.

Table 1

Example Survey Questions and Response Options

\begin{tabular}{lll} 
& Example Questions & Sample Response Options \\
\hline 1 & What is your skill level in team presentations? & 1 to 10 scale \\
\hline
\end{tabular}


Table 1 Cont.

\begin{tabular}{|c|c|c|}
\hline & Example Questions & Sample Response Options \\
\hline 2 & What is your skill level in writing? & 1 to 10 scale \\
\hline 3 & $\begin{array}{l}\text { How close to the deadline do you get work completed? } 1 \text { is } \\
\text { well in advance and } 10 \text { is right before it is due }\end{array}$ & 1 to 10 scale \\
\hline 4 & $\begin{array}{l}\text { How quickly do you respond to communications (emails, texts, } \\
\text { Slack, etc.) from teammates? }\end{array}$ & Open-ended \\
\hline 5 & $\begin{array}{l}\text { How many hours per week (on average) do you see yourself } \\
\text { working on the team project? }\end{array}$ & Open-ended, or ranges provided \\
\hline 6 & What is your skill level in creating PowerPoint slides? & 1 to 10 scale \\
\hline 7 & $\begin{array}{l}\text { What roles would you like to play in/on the team for this } \\
\text { project? }\end{array}$ & $\begin{array}{l}\text { Open-ended, or options if they } \\
\text { exist }\end{array}$ \\
\hline 8 & $\begin{array}{l}\text { Please share your relevant strengths and weaknesses } \\
\text { (opportunities for improvement) }\end{array}$ & Open-ended \\
\hline
\end{tabular}

\section{Teammate Preferences (Touch Point C)}

After gathering all students' self-assessment results, the instructor shares the responses from every class member with the entire class. The instructor may opt to anonymize responses before sharing or opt to keep the names. If names are retained, students may select based on the specific person and not their ratings. For this reason, we typically recommend removing names and assigning an anonymous letter or number to each student. However, many students have shared-leading to a great discussion - that having names is valuable as sometimes self-assessments do not align with actual behaviors/performance. Based on the authors' experience, including names can help if students do not want to be paired with a specific person based on a difficult prior experience. Alternatively, instructors can provide a way for students to submit names of classmates with whom they specifically do not want to be paired; this way, instructors can maintain anonymity with the data while honoring students' wishes.

Whether the instructor chooses anonymity or not, students may inflate their responses. In Psychology courses, the phenomena of students inflating their selfassessments can lead to a discussion of self-serving attributes and associated biases (i.e., social desirability) (Karpen, 2018). We recommend instructors include a discussion in the beginning of the process regarding accountability and team profiles. A student's team members will be provided with that student's survey answers with the team profile (see Touch Point D), creating an element of accountability. If the student does not possess the skills or characteristics they claimed, the team will discover the inconsistency and realize that the student did not tell the truth. This is typically not a scenario in which a student wants to find themselves.

After all student survey responses are shared with the class, instructors can either create an assignment where students submit their teammate preferences with rationales or create another survey asking students to rank their top five or six teammate options. We encourage instructors to have students submit more than the minimum required for a team to create more options when forming teams. As this submission is only shared with the instructor, we require students to provide a written explanation for each teammate preference indicated. The explanations provide the student insights into how and why they select teammates. These explanations and associated insights can provide for a future learning opportunity if an assignment is 
created later that asks students to reflect on their teammate selections and consider what worked/did not work and why.

Diagram 1 indicates Touch Point $C$ occurring during class two. The authors found it works effectively for students to complete the preference ranking during the class meeting, if in-person or synchronous online, to ensure timely completion. Allocating a few minutes of class time provides the instructor all the information needed to create teams after class two.

\section{Team Profile (Touch Point D)}

After all teammate preferences are submitted in Touch Point C, the instructor can use different approaches to form teams. Using Excel functionality on downloaded data, like sorting, highlighting with different colors, and moving data among cells, can be helpful in building teams. Pairing students who picked each other can be a nice place to start building teams. When possible, we suggest each person receives at least one to two people they requested on their team to evidence their participation in the team formation process.

After the instructor creates the teams, the teams' initial activity is to evaluate their collective profile on the team success factors. The instructor can create the team profiles in Excel using the survey data. See Appendix B for an example team profile. As an initial team activity, each team can review their profile to identify strengths as well as potential issues that could hinder success for the specific class project based on the team profile. For example, if the team project requires a specific skill like building a website and no one has experience with website design, then this is brought to everyone's attention at the start of the project. The team can generate a plan to address these specific areas. Teams can verbally report out in class and synchronous online meetings or submit their plans to the instructor as an initial team assignment.

Our process can be followed by or paired with other team activities to foster effective dynamics in class project teams. Options include a team charter or team ground rules, peer ratings based on the identified criteria (Aaron et al., 2014), and a textual mapping of member skills relevant to the project criteria (Goltz, 2017). In an interdisciplinary Creativity course, an author found that developmental non-graded peer assessments tied to the factors on the team profile aided students in providing peer feedback.

By the time teams begin project work, students have considered the team success factors from Touch Point A (individually or collectively) at least four times. These touch point opportunities facilitate increased student awareness and set the foundation for learning, self-improvement, team and individual goal-setting, and effective team performance.

\section{The Participative Process and Course Modalities}

The participative team formation process can be facilitated (1) in-person/faceto-face, (2) virtually/synchronous online and/or (3) asynchronous online class formats. For hybrid formats, instructors can select the parts to be delivered in person and online. See Table 2 for the differences in the processes based on the class format. 
Table 2

Participative Team Formation Process Across Course Modalities

\begin{tabular}{|c|c|c|c|}
\hline Touch Point & Face to Face Learning & Synchronous Online & Asynchronous Online \\
\hline $\begin{array}{l}\text { Identification and } \\
\text { Explanation (A) }\end{array}$ & $\begin{array}{l}\text { - Introduce project } \\
\text { - Capture student } \\
\text { ideas on team project } \\
\text { effective behaviors a } \\
\text { board/display }\end{array}$ & $\begin{array}{l}\text { - Introduce project } \\
\text { - Live virtual session, } \\
\text { with potential break } \\
\text { out groups to discuss } \\
\text { and generate } \\
\text { effective team } \\
\text { behaviors }\end{array}$ & $\begin{array}{l}\text { - Introduce project via } \\
\text { video } \\
\text { Discussion posts or } \\
\text { activity assignment } \\
\text { where student will } \\
\text { submit effective team } \\
\text { behaviors after } \\
\text { learning about project }\end{array}$ \\
\hline Self-Assessment (B) & \multicolumn{3}{|c|}{$\begin{array}{l}\text { - Instructor creates survey in software (i.e. Google Forms), all students } \\
\text { complete } \\
\text { - To achieve quicker completion rates, this can be facilitated during a class } \\
\text { session in in-person and synchronous formats }\end{array}$} \\
\hline Teammate Preferences (C) & \multicolumn{3}{|c|}{$\begin{array}{l}\text { - Instructor distributes entire classes survey results to the class, option to } \\
\text { include or disguise names } \\
\text { - Students rank teammate preferences via assignment, email, or an } \\
\text { additional survey } \\
\text { - Based on student submitted rankings, instructor begins forming teams } \\
\text { - Different approaches can be used to form teams, but starting with people } \\
\text { who select each other can be helpful }\end{array}$} \\
\hline Team Profile (D) & $\begin{array}{l}\text { - Assemble teams in } \\
\text { class } \\
\text { - Create and distribute } \\
\text { team profiles } \\
\text { - Students meet new } \\
\text { team members and } \\
\text { review team profiles } \\
\text { to identify potential } \\
\text { obstacles to success }\end{array}$ & $\begin{array}{l}\text { - Create and distribute } \\
\text { team profiles via } \\
\text { email or online } \\
\text { learning platform } \\
\text { - Create online } \\
\text { breakout sessions for } \\
\text { groups to identify } \\
\text { potential obstacles } \\
\text { - Instructor can toggle } \\
\text { between groups }\end{array}$ & $\begin{array}{l}\text { - Create and distribute } \\
\text { team profiles via email } \\
\text { or online learning } \\
\text { platform } \\
\text { - Form groups through } \\
\text { online learning } \\
\text { system. Students can } \\
\text { meet though video or } \\
\text { though written posts } \\
\text { to identify potential } \\
\text { obstacles to success }\end{array}$ \\
\hline
\end{tabular}

\section{Student Feedback}

The process has been facilitated across in-person and online courses. Student feedback from a fall 2019 in-person class, captured via an anonymous survey, was mostly positive. The negative feedback was associated with students who already knew their classmates, indicating this process may be more effective in lower-level courses.

- Really good, a "smart" process to find team members for a project. I thought that the survey we formed together was the best part.

- I was a huge fan of the team formation process. I have never had this done before and have at times not been satisfied with my team. It has been very clear in our performance that it was a good match. 
- I really enjoyed the process because it forced us to reflect on ourselves and get to see how others answer about themselves.

- I believe it will be more effective in classes where you do not know anyone and thus, have not formed any previous biases.

- The team formation was a good experience. Should I not have known most of my classmates, I believe I would have benefitted more from the experience.

\section{Conclusion}

The participative team formation process provides opportunities for students to both participate in and learn from each touch point in the process. Based on our experiences across multiple classes, the process can foster increased awareness of effective team characteristics via consideration of the team's profile (or the foundation of a team mental model), set clear team goals or visions, expand

As team skills are desired by employers, students can leverage key learnings from [the participative team formation] process in job interviews when asked to share experiences of effective teamwork. understanding regarding one's own developmental needs (or self-regulation), as well as help to foster a valuable and successful class project team experience (or group/team potency). The process can provide a foundation of awareness and understanding to support team skill development in future class team projects. As team skills are desired by employers, students can leverage key learnings from this process in job interviews when asked to share experiences of effective teamwork.

\section{References}

Aaron, J. R., McDowell, W. C., \& Herdman, A. O. (2014). The effects of a team charter on student team behaviors. Journal of Education for Business, 89(2), 9097. https://doi.org/10.1080/08832323.2013.763753

Baepler, P., Walker, J. D., Brooks, D. C., Saichaie, K., \& Petersen, C. I. (2016). A guide to teaching in the active learning classroom: History, research, and practice. Stylus Publishing, LLC.

Baird, A., \& Parayitam, S. (2019). Employers' ratings of importance of skills and competencies college graduates need to get hired: Evidence for the New England region of USA. Education E Training, 61(5), 622-634. http://dx.doi.org/10.1108/ET-12-2018-0250

Barkley, E. F., Cross, K. P., \& Major, C. H. (2014). Collaborative learning techniques: A handbook for college faculty ( $2^{\text {nd }}$ ed.). Jossey-Bass.

Burbach, M. E., Matkin, G. S., Gambrell, K. M., \& Harding, H. E. (2010). The impact of preparing faculty in the effective use of student teams. College Student Journal, 44(3), 752-762.

Campion, M. A., Medsker, G. J., \& Higgs, A. C. (1993). Relations between work group characteristics and effectiveness: Implications for designing effective work groups. Personnel Psychology, 46(4), 823-847.

https://onlinelibrary.wiley.com/doi/abs/10.1111/j.1744-6570.1993.tb01571.x 
DeChurch, L. A., \& Mesmer-Magnus, J. R. (2010). The cognitive underpinnings of effective teamwork: A meta-analysis. Journal of Applied Psychology, 95(1), 3253. https://doi.org/10.1037/a0017328

Decker, R. (1995). Management team formation for large scale simulations. Developments in Business Simulation and Experiential Learning: Proceedings of the Annual ABSEL Conference (Vol. 22).

DuFrene, D. D., \& Lehman, C. M. (1996). Achieving self-directed work team skills through cooperative learning. Paper presented at the Annual Meeting of the Southwest Educational Association Convention, New Orleans, LA.

Edwards, B. D., Day, E. A., Arthur, W., Jr., \& Bell, S. T. (2006). Relationships among team ability composition, team mental models, and team performance. Journal of Applied Psychology, 91(3), 727-736.

https://psycnet.apa.org/doiLanding?doi=10.1037\%2F0021-9010.91.3.727

Goltz, S. M. (2017). Enhancing simulation learning with team mental model mapping. Management Teaching Review, 2(3), 211-224.

https://doi.org/10.1177/2379298117706335

Howe, J. L., Hyer, K., Mellor, J., Lindeman, D., \& Luptak, M. (2001). Educational approaches for preparing social work students for interdisciplinary teamwork on geriatric health care teams. Social Work in Health Care, 32(4), 19-42. https://doi.org/10.1300/J010v32n04 02

$\mathrm{Hu}$, J., \& Liden, R. C. (2011). Antecedents of team potency and team effectiveness: An examination of goal and process clarity and servant leadership. Journal of Applied Psychology, 96(4), 851-862. https://doi.org/10.1037/a0022465

Jahanbakhsh, F., Fu, W. T., Karahalios, K., Marinov, D., \& Bailey, B. (2017). You want me to work with who? Stakeholder perceptions of automated team formation in project-based courses. Proceedings of the 2017 CHI Conference on Human Factors in Computing Systems (pp. 3201-3212). Urbana, IL.

https://dl.acm.org/doi/10.1145/3025453.3026011

Karpen, S. C. (2018). The social psychology of biased self-assessment. American Journal of Pharmaceutical Education, 82(5), 441-448. https://doi.org/10.5688/ajpe6299

Kruse, K. (2020, April 17). Skill gap 2020: 5 soft skills and 10 hard skills companies need now. Forbes.

https://www.forbes.com/sites/kevinkruse/2020/04/17/skill-gap-2020-5-softskills-and-10-hard-skills-companies-need-now/?sh=4ed7661d6356

Nilson, L. B. (2010). Teaching at its best: A research-based resource for college instructors. Jossey-Bass.

Opatrny, C., McCord, M., \& Michaelsen, L. (2014). Can transferable team skills be taught? A longitudinal study. Academy of Educational Leadership Journal, 18(2), 61-72.

Prichard, J. S., Bizo, L. A., \& Stratford, R. J. (2006). The educational impact of team-skills training: Preparing students to work in groups. British Journal of Educational Psychology, 76(1), 119-140.

https://doi.org/10.1348/000709904X24564

Prichard, J. S., Stratford, R. J., \& Hardy, C. (2004). Training students to work in teams: Why -and how? LTSN Psychology. 
Snyder, L. G. (2008), The use of pre-group instruction to improve student collaboration. Proceedings of the Delta Pi Epsilon Conference (pp. 65-69), Chicago, IL.

Stevenson, K., Seenan, C., Morlan, G., \& Smith, W. (2012). Preparing students to work effectively in interprofessional health and social care teams. Quality in Primary Care, 20(3), 227-230.

Turan, S., Demirel, O., \& Sayek, I. (2009). Metacognitive awareness and self-regulated learning skills of medical students in different medical curricula. Medical Teacher, 31(10), e477-e483.

https://doi.org/10.3109/01421590903193521

Weimer, M. (2010). What it means to be a self-regulated learner. Practice, 41(2), 64-70. 


\section{Appendices}

\section{Appendix A}

\section{Sample Survey Questions and Response Options}

\begin{tabular}{|c|c|c|}
\hline & Sample Questions & Sample Response Options \\
\hline 1 & What is your skill level in team presentations? & 1 to 10 scale, 10 is highest \\
\hline 2 & What is your skill level in writing? & 1 to 10 scale, 10 is highest \\
\hline 3 & $\begin{array}{l}\text { How close to the deadline do you get work completed? } 1 \\
\text { is well in advance and } 10 \text { is right before it is due. }\end{array}$ & 1 to 10 scale \\
\hline 4 & $\begin{array}{l}\text { In project groups, are you more of a leader (10), follower } \\
(1) \text {, or somewhere in-between? }\end{array}$ & 1 to 10 scale \\
\hline 5 & What grade do you desire to earn on this project? & A, B, C or below \\
\hline 6 & What is your class year standing? & $\begin{array}{l}\text { First-year, sophomore, junior, } \\
\text { or senior }\end{array}$ \\
\hline 7 & What is your major? & $\begin{array}{l}\text { Open-ended or list of major } \\
\text { options }\end{array}$ \\
\hline 8 & What is your minor (if applicable)? & $\begin{array}{l}\text { Open-ended or list of minor } \\
\text { options }\end{array}$ \\
\hline 9 & $\begin{array}{l}\text { How important is it to you to have fun with the } \\
\text { project/team? }\end{array}$ & $\begin{array}{l}1 \text { to } 10 \text { scale, with } 10 \text { as most } \\
\text { important }\end{array}$ \\
\hline 10 & $\begin{array}{l}\text { How often do you desire to meet (either virtually or in- } \\
\text { person) with your team? }\end{array}$ & Open-ended \\
\hline 11 & $\begin{array}{l}\text { How many hours per week (on average) do you see } \\
\text { yourself working on the team project? }\end{array}$ & $\begin{array}{l}\text { Open-ended, or ranges } \\
\text { provided }\end{array}$ \\
\hline 12 & $\begin{array}{l}\text { What days and times are you available to meet with } \\
\text { teammates? }\end{array}$ & Open-ended \\
\hline 13 & $\begin{array}{l}\text { How quickly do you respond to communications (emails, } \\
\text { texts, etc.) from teammates? }\end{array}$ & Open-ended \\
\hline 14 & $\begin{array}{l}\text { How quickly do you expect teammates to respond to } \\
\text { communications (emails, texts, etc.) from you? }\end{array}$ & Open-ended \\
\hline 15 & $\begin{array}{l}\text { How many years of real-world working experience do you } \\
\text { have? }\end{array}$ & Open-ended \\
\hline 16 & $\begin{array}{l}\text { If prior class project teammates rated you on your overall } \\
\text { performance, what rating would they assign? } 10 \text { is } \\
\text { highest, and } 1 \text { is lowest }\end{array}$ & $\begin{array}{l}1 \text { to } 10 \text { scale, with } 10 \text { as highest } \\
\text { or best rating }\end{array}$ \\
\hline 17 & What is your skill level in creating PowerPoint slides? & 1 to 10 scale, 10 is highest \\
\hline 18 & What is your skill level in conducting financial analysis? & 1 to 10 scale, 10 is highest \\
\hline 19 & $\begin{array}{l}\text { What experience or knowledge do you have with the } \\
\text { subject area of the project? }\end{array}$ & 1 to 10 scale, 10 is highest \\
\hline 20 & What is your interest level in the project? & 1 to 10 scale, 10 is highest \\
\hline 21 & $\begin{array}{l}\text { What roles would you like to play in/on the team for this } \\
\text { project? }\end{array}$ & $\begin{array}{l}\text { Open-ended, or options if they } \\
\text { exist }\end{array}$ \\
\hline 22 & $\begin{array}{l}\text { Please share your relevant strengths and weaknesses } \\
\text { (opportunities for improvement). }\end{array}$ & Open-ended \\
\hline 23 & My biggest potential obstacle with this project is... & Open-ended \\
\hline 24 & I will feel good at the end of the project if... & Open-ended \\
\hline 25 & $\begin{array}{l}\text { Is there anything else you would like to share with } \\
\text { potential teammates? }\end{array}$ & Open-ended \\
\hline
\end{tabular}




\section{Appendix B}

Example of Team Profile (based on individual survey results)

\begin{tabular}{|c|c|c|c|c|}
\hline $\begin{array}{l}\text { Survey Question / } \\
\text { Teammate Name }\end{array}$ & Marcus & Jasmyn & Chloe & Craig \\
\hline $\begin{array}{l}\text { What is your skill level } \\
\text { in team presentations? } \\
10 \text { is highest }\end{array}$ & 4 & 8 & 9 & 5 \\
\hline $\begin{array}{l}\text { What is your skill level } \\
\text { in writing? } 10 \text { is } \\
\text { highest }\end{array}$ & 8 & 7 & 10 & 4 \\
\hline $\begin{array}{l}\text { How close to the } \\
\text { deadline do you get } \\
\text { work completed? } 1 \text { is } \\
\text { well in advance and } 10 \\
\text { is right before it is due }\end{array}$ & 5 & 4 & 7 & 2 \\
\hline $\begin{array}{l}\text { How quickly do you } \\
\text { respond to } \\
\text { communications } \\
\text { (emails, texts, Slack, } \\
\text { etc.) from teammates? }\end{array}$ & 2 to 3 hours & 4 to 6 hours & Within a day & An hour or so \\
\hline $\begin{array}{l}\text { How many hours per } \\
\text { week (on average) do } \\
\text { you see yourself } \\
\text { working on the team } \\
\text { project? }\end{array}$ & 4 & 1 to 2 & 4 to 6 & 2 at most \\
\hline $\begin{array}{l}\text { What is your skill level } \\
\text { in creating PowerPoint } \\
\text { slides? } 10 \text { is highest }\end{array}$ & 5 & 6 & 2 & 9 \\
\hline $\begin{array}{l}\text { What roles would you } \\
\text { like to play in/on the } \\
\text { team for this project? }\end{array}$ & $\begin{array}{l}\text { Anything } \\
\text { other than } \\
\text { presenting }\end{array}$ & $\begin{array}{l}\text { Open to } \\
\text { everything }\end{array}$ & Leader & $\begin{array}{l}\text { Compiling } \\
\text { presentation }\end{array}$ \\
\hline $\begin{array}{l}\text { Please share your } \\
\text { relevant strengths and } \\
\text { weaknesses } \\
\text { (opportunities for } \\
\text { improvement) }\end{array}$ & $\begin{array}{l}\text { I meet all } \\
\text { deadlines. I } \\
\text { get nervous } \\
\text { when } \\
\text { presenting. }\end{array}$ & $\begin{array}{l}\text { I enjoy team } \\
\text { projects. I } \\
\text { think I } \\
\text { generally } \\
\text { invest a lot } \\
\text { of time in } \\
\text { them. }\end{array}$ & $\begin{array}{l}\text { I like taking } \\
\text { the lead on } \\
\text { areas where } \\
\text { I am strong. } \\
\text { Sometimes I } \\
\text { don't listen } \\
\text { as well as I } \\
\text { should. }\end{array}$ & $\begin{array}{l}\text { I am good at } \\
\text { time } \\
\text { management, } \\
\text { as I play a } \\
\text { sport. That } \\
\text { also means I } \\
\text { am limited in } \\
\text { meeting } \\
\text { times. }\end{array}$ \\
\hline
\end{tabular}


Dr. Greg Berka is an assistant professor of management at Queens University of Charlotte. He teaches decision-making, creativity, and organizational behavior across the undergraduate, $M B A$, and Master of Talent and Organization Development programs. He supports many entrepreneurial initiatives across the university and enjoys developing case studies with small business owners. He loves teaching and sees a great deal of value in the Scholarship of Teaching and Learning as it helps him to be student-focused and encourages experimenting with new approaches.

Amber Greenwood is a doctoral student in the Organizational Science PhD Program at the University of North Carolina at Charlotte. She received her MA in Industrial-Organizational Psychology from UNC Charlotte and her BS in Psychology with a statistics minor from the University of Georgia. Amber teaches Business Communication, Quantitative Analysis, and Personality. Her research interests include perceptions of busyness, impression management, and the scholarship of teaching and learning.

Dr. Jae Hwan Lee is an assistant professor at Hamline University. He teaches strategic management capstone courses to both undergraduate and MBA students. He received his $P h D$ from Texas Tech University and MBA from Brigham Young University. He also obtained MA in Political Science and BA in Communication both from Seoul National University in South Korea. His research interests include stakeholder theory and corporate social responsibility/corporate citizenship. His work has been published in various management journals including the Journal of Business Ethics and Business \& Society.

"What should college mean, in a millennium where knowledge itself is literally everywhere, no longer cloistered, forbidden, or hidden? We're still about knowledge,

but in a different way, no longer tasked with simply preserving, curating, and transmitting what's already known. Instead, we need to be mostly about creating more of it" (p. 6).

O'Donnell, K. (2021). Good for what ails us. Journal of the Scholarship of Teaching and Learning, 21(1).

https://scholarworks.iu.edu/journals/index.php/josotl/article/view/32464 